\title{
Primary Bone Diffuse Large B-cell Lymphoma with Multifocal Osteolytic Lesions: A Rare Entity
}

Georgia Kaiafa ${ }^{1}$, Trantafyllos Didangelos ${ }^{2^{*}}$, Matthew Bobos ${ }^{3}$, Eleni Karlafti ${ }^{4}$, Eleftheria Ztriva ${ }^{4}$, Ilias Kanellos ${ }^{4}$, and Christos Savopoulos $^{4}$

${ }^{1}$ Department of Haematology, 1st Propedeutic Internal Medicine Clinic of University Hospital AHEPA, Aristotle University of Thessaloniki, Greece

${ }^{2}$ Internal Medicine, 1st Propedeutic Internal Medicine Clinic of University Hospital AHEPA, Aristotle University of Thessaloniki, Greece

${ }^{3}$ Laboratory of Pathological Anatomy, Aristotle University of Thessaloniki, Greece

${ }^{4}$ Internal Medicine Clinic of University Hospital AHEPA, Aristotle University of Thessaloniki, Greece

"Corresponding author: Trantafyllos Didangelos, Internal Medicine, 1st Propedeutic Internal Medicine Clinic of University Hospital AHEPA, Aristotle University of Thessaloniki, Greece, Tel: +30 6944863803; Fax: +30 2310994776; E-mail: didang@med.auth.gr

Rec date: January 23, 2018; Acc date: January 25, 2018; Pub date: January 29, 2018

Copyright: (c) 2018 Kaiafa G, et al. This is an open-access article distributed under the terms of the Creative Commons Attribution License, which permits unrestricted use, distribution, and reproduction in any medium, provided the original author and source are credited.

\begin{abstract}
Bone lymphomas can be classified as primary (PBL), or secondary ( $\mathrm{SBL}$ ). $\mathrm{PBL}$ is a rare entity, accounting for approximately $7 \%$ of malignant bone tumors, $5 \%$ of extra nodal lymphomas and $<1 \%$ of all non-Hodgkin lymphomas. We present here a case of multifocal bone lymphoma in a 72-year old female patient, who was admitted to our clinic for further investigation of persistent back pain, anorexia, weight loss and fatigue. There were no palpable lymph nodes, no hepatosplenomegaly or neurological signs. Her laboratory tests showed a moderate elevation of LDH, ESR and beta-2 microglobulin. In CT and MRI scan a complete fracture of the left hip and multiple vertebral lesions were revealed. Bone biopsy of the left hip showed a Diffuse Large B-cell Lymphoma. She was treated with combined chemotherapy (R-CHOP regimen) plus radiation, followed by bracing with cervical immobilization and cimentoplasty of lumbar vertebrae. She achieved complete response and she is alive at last follow-up.
\end{abstract}

Keywords: Bone lymphoma; Primary bone lymphoma; Diffuse Large B-cell lymphoma; Chemotherapy; Radiation; Cimentoplasty.

\section{Case Report}

A 72-year-old female patient, without any notable medical or family history presented to her general practitioner with persistent middle back pain and failure of common analgesics to ease the pain. Anorexia, weight loss of about $6 \mathrm{~kg}$ in the last 3 months and fatigue were also reported. An outpatient MRI of thoracic and lumbar spine revealed a complete fracture of the T10 vertebra and multiple, high signal vertebral lesions indicative of secondary origin (Figures 1 and 2). Then she was referred to our department for further investigation.

Physical examination was notable for back pain at the level of $\mathrm{T}_{10}$, reproducible by palpation. There were no palpable lymph nodes, no hepatosplenomegaly or neurological signs. Blood tests showed a normal full blood count, with mild hypercalcemia, moderate LDH and beta-2 microglobulin elevation and no paraprotein on the electrophoresis. In detail her hematological profile was as follows: Hct: 39\%, Hb: 12,7 g/dl, MCV: $92 \mathrm{fl}, \mathrm{MCH}: 30 \mathrm{pg}, \mathrm{MCHC}: 33.3 \mathrm{~g} / \mathrm{dl}$, reticulocytes: $1.6 \%$; WBC: $8.6 \times 10^{9}$ cells/L (neutrophils $65 \%$ lymphocytes: $30 \%$ - monocytes: 5\%); PLT: $349 \times 10^{9} / \mathrm{L}$, ESR: $60 \mathrm{~mm}$, and CRP: $0.5 \mathrm{mg} / \mathrm{dl}$ (normal range: $0-0.8 \mathrm{mg} / \mathrm{dl}$ ). Serum biochemistry showed a moderate elevation of LDH: $380 \mathrm{U} / \mathrm{L}$ (normal range: 135-214 $\mathrm{U} / \mathrm{L}$ ), normal total proteins: $7.1 \mathrm{~g} / \mathrm{L}$ (normal range: 6.6- $8.7 \mathrm{~g} / \mathrm{L}$ ), elevated calcium: $11.8 \mathrm{mg} / \mathrm{dl}$ (normal range: $8.2-10.6 \mathrm{mg} / \mathrm{dl}$ ), and elevated beta- 2 microglobulin: $4.1 \mathrm{mg} / \mathrm{L}$ (normal range: 1.42-3.21 $\mathrm{mg} / \mathrm{L}$ ). HBV, HCV, HIV, EBV and other serologic and immunologic investigations were negative.

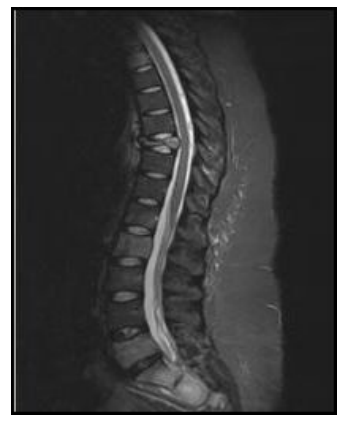

Figure 1: T2 Spine MRI showing complete T10 fracture and multiple vertebral lesions.

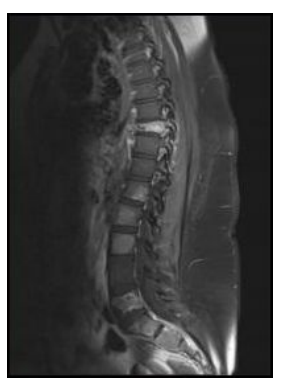

Figure 2: T1 Spine MRI showing complete T10 fracture and multiple vertebral lesions. 
Citation: Georgia Kaiafa, Trantafyllos Didangelos, Matthew Bobos, Eleni Karlafti, Eleftheria Ztriva, et al. (2018) Primary Bone Diffuse Large Bcell Lymphoma with Multifocal Osteolytic Lesions: A Rare Entity. Gen Med (Los Angeles) 6: 308. doi:4172/2327-5146.1000308

Page 2 of 3

Thoraco-abdominal-pelvis CT revealed multiple osteolytic lesions of the spine (T3, T5, T6, T8, T10, L1, L2, L3, L5), sacrum, iliac crests and pubic symphysis, both iliopubic branches and a complete pathological T10 fracture (Figures 3 and 4). Otherwise no lympadenopathy or hepatosplenomegaly were detected. Furthermore a PET-CT confirmed hypermetabolic osteolytic bone lesions (SUV max at 10), without any image suggestive of primitive cancer.

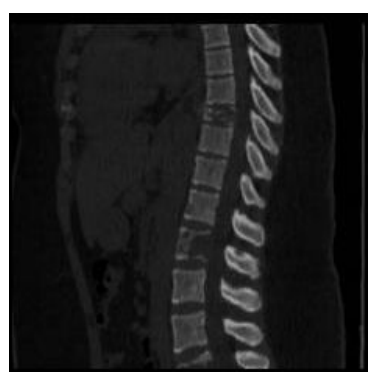

Figure 3: CT images showing osteolytic lesions of the spine.

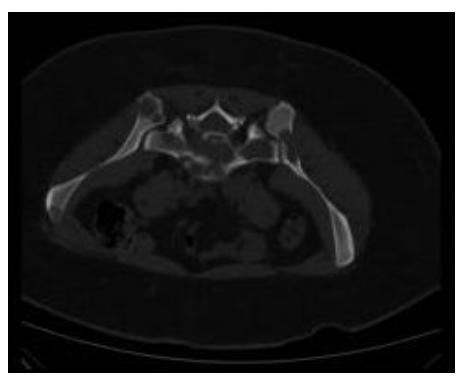

Figure 4: CT images showing osteolytic lesions of the sacrum and iliac crests.

A guided bone biopsy of the left hip revealed a diffuse infiltration of medium to large -sized lymphoid cells, mainly centroblasts with scattered immunoblasts, with focal atypia. The immunohistochemical investigation showed the following tumor-cell immunophenotype: $\mathrm{CD}_{20}^{+}, \mathrm{CD}^{-}, \mathrm{CD}_{10}^{-}, \mathrm{Bcl}^{+}, \mathrm{MUM1}^{+}, \mathrm{CD}^{-} 0^{-}, \mathrm{EBER}^{-}, \mathrm{Ki} 67: 75 \%$. Cytogenetics by FISH analysis showed BCL6 rearrangement, BCL2 and MYC normal gene status. Based on morphological, immunohistochemical, and molecular data the diagnosis of Diffuse Large B-cell lymphoma, not other specified (DLBCL-NOS) of nongerminal-centre phenotype was made. Bone marrow biopsy showed no evidence of lymphoma involvement.

According to the clinical and imaging examination the patient was classified as stage IVE (IELSG), IV (Ann Arbor), risk group 4 (IPI) (LDH 380, Stage IV, >1 extranodal site). She was treated with combined chemotherapy, 4 cycles of R-CHOP regimen (every 3 weeks) plus radiation of the thoracic spine (2000 cGy in 4 courses), followed by bracing with cervical immobilization and cimentoplasty of lumbar vertebrae. She achieved complete response and she is alive at last follow-up, after 2 years.

\section{Discussion}

Bone lymphomas can be classified as primary bone lymphomas (PBL), consisting of unifocal lymphoma (with or without regional lymphadenopathies) and multifocal- polyostotic lymphoma (with multifocal disease exclusively involving the skeleton; without affecting lymph nodes or other integral organ and secondary (disseminated) lymphomas (SBL) with secondary infiltration of the skeleton [1]. The criteria for the diagnosis of primary bone lymphoma are described by Coley et al. (see ref) (Coley's criteria) and includes: (a): A primary focus in a single bone, (b) unequivocal histologic proof from the bone lesion, and (c) no evidence of distant soft tissue or distant lymph node involvement.

Nevertheless it is difficult in many cases to distinguish the primary site of lymphoma and to categorize it as primary or secondary [2]. PBL account for about $5 \%$ of extranodal lymphomas, $<1 \%$ of all nonHodgkin lymphomas (NHL) and 3-7\% of all malignant bone tumours [3]. Median age at diagnosis ranges between 45 and 60 years old with a male prevalence, while paediatric cases have been also reported [4]. The main patient characteristics are: pain (80-95\%) and pathological fracture (15-20\%). Pelvic bones and spinal cord are commonly affected, while hypercalcemia and osteolysis can be observed [5]. Diagnosis must be confirmed by histopathological examination of a biopsy (Table 1 ), obtained by surgical procedure, limited in size due to the risk of pathological fracture [6].

Diffuse Large B-cell lymphoma (DLBCL) accounts for the majority of cases (70-80\% of all bone lymphomas) [7]. Primary bone DLBCL has usually specific molecular characteristics in comparison with other extranodal B-cell lymphomas (MUM1 positivity, BLC6 mutations) [8].

\begin{tabular}{|l|l|l|l|}
\hline Classification & uPBL & mPBL & SBL \\
\hline DLBCL, n (\%) & $37(80.4)$ & $23(66.7)$ & $23(50.0)$ \\
\hline Folicular lymphoma, n (\%) & $4(8.7)$ & $3(8.6)$ & $9(19.6)$ \\
\hline Small lymphocytic lymphoma, n (\%) & $1(2.2)$ & $1(29)$ & $0(0)$ \\
\hline Marginal zone lymphoma, n (\%) & $1(2.2)$ & $1(29)$ & $2(4.3)$ \\
\hline Not further subclassifiedo, n (\%) & $1(2.2)$ & $2(5.7)$ & $1(2.2)$ \\
\hline BLUI, n (\%) & 0 & $1(29)$ & $0(0)$ \\
\hline Classical Hodgin lymphoma, n (\%) & $1(2.2)$ & $0(0)$ & $10(21.7)$ \\
\hline T cell, n (\%) & $1(2.2) \mathrm{b}$ & $4(11.4) \mathrm{c}$ & $1(2.2) \mathrm{d}$ \\
\hline Total, n (\%) & 46 & 35 & 46 \\
\hline
\end{tabular}

Table 1: Histopathological subtypes of patients with bone lymphoma.

Stage of the disease is defined according to the Ann Arbor and the IELSG staging system (Table 2) [2]. The survival of patients with primary bone DLBCL is related to disease stage, while it is independently associated with age, performance status and serum LDH levels [9]. Prognosis seems to be better in patients with multifocal DLBCL compared to disseminated nodal lymphoma; MUM 1 expression $>10 \%$, low CD10 expression and a nongerminal centre signature are associated with poorer outcome [10]. Relapses are sign of poor prognosis [5], while presentation at the initial onset of the disease with pathological fracture is associated with worst outcome [11]. Firstline treatment should be based on R-CHOP regimens followed when indicated by involved-field radiotherapy and CNS prophylaxis in high risk patients. With this strategy the overall response rate (ORR) is over $90 \%$ and the 5 -year overall survival is $84 \%$ [5]. However there still remain several issues with regard the sequence of treatment, the choice 
Citation: Georgia Kaiafa, Trantafyllos Didangelos, Matthew Bobos, Eleni Karlafti, Eleftheria Ztriva, et al. (2018) Primary Bone Diffuse Large Bcell Lymphoma with Multifocal Osteolytic Lesions: A Rare Entity. Gen Med (Los Angeles) 6: 308. doi:4172/2327-5146.1000308

Page 3 of 3

of radiation volume and the role of surgery for fixation of pathological fractures.

\begin{tabular}{|l|l|l|}
\hline $\begin{array}{l}\text { IELSG } \\
\text { stage }\end{array}$ & Lymphoma extension & $\begin{array}{l}\text { Ann } \\
\text { stage }\end{array}$ \\
\hline IE & Single bony lesion & IE \\
\hline II E & Single bony lesion with involvement of regional lymph nodes & II E \\
\hline IV E & $\begin{array}{l}\text { Multifocal disease in a single bone or lesion in multiple bones in a disease exclusively limited to the skeleton (without lymph nodal or } \\
\text { visceral disease) }\end{array}$ & IV \\
\hline IV & Disseminated lymphoma with at least one bony lesion & IV \\
\hline
\end{tabular}

Table 2: IELSC staging system for DLBCL of the bone.

\section{References}

1. Alencar A, Pitcher D, Byrne G, Lossos IS (2010) Primary bone lymphoma-the University of Miami experience. Leukemia \& lymphoma 51:39-49.

2. Messina C, Christie D, Zucca E, Gospodarowicz M, Ferreri AJ (2015) Primary and secondary bone lymphomas. Cancer Treat Rev 41: 235-246.

3. Mikhaeel NG (2012) Primary bone lymphoma. Clin Oncol (R Coll Radiol) 24:366-370.

4. Zhao XF, Young KH, Frank D, Goradia A, Glotzbecker MP, et al. (2007) Pediatric primary bone lymphoma-diffuse large B-cell lymphoma: Morphologic and immunohistochemical characteristics of 10 cases. Am J Clin Pathol 127: 47-54.

5. Ramadan KM, Shenkier T, Sehn LH, Gascoyne RD, Connors JM (2007) A clinicopathological retrospective study of 131 patients with primary bone lymphoma: a population-based study of successively treated cohorts from the British Columbia Cancer Agency. Ann Oncol 18: 129-135.

6. Theodorou DJ, Theodorou SJ, Sartorius DJ, Haghighi P, Resnick D (2000) Delayed diagnosis of primary non-Hodgkin's lymhoma of the sacrum. Clin Imaging 24: 169-173.
7. Beal K, Allen L, Yahalom J (2006) Primary bone lymphoma: Treatment results and prognostic factors with long-term follow-up of 82 patients. Cancer 106: 2652-2656.

8. Falini B, Fizzotti M, Pucciarini A, Bigerna B, Marafioti T, et al. (2006) A monoclonal antibody (MUM1p) detects expression of the MUM1/IRF4 protein in a subset of germinal center B cells, plasma cells, and activated T cells. Blood 95: 2084-2092.

9. Messina C, Ferreri AJ, Govi S, Bruno-Ventre M, Gracia Medina EA, et al. (2014) International Extranodal Lymphoma Study Group (I.E.L.S.G.). Clinical features, management and prognosis of multifocal primary bone lymphoma: a retrospective study of the international extranodal lymphoma study group (the IELSG 14 study). Br J Haematol 164: 834-840.

10. Adams H, Tzankov A, d'Hondt S, Jundt G, Dirnhofer S, et al. (2008) Primary diffuse large B-cell lymphomas of the bone: prognostic relevance of protein expression and clinical factors. Hum Pathol 39: 1323-1330.

11. Govi DS, Christie C, Messina M, Bruno Ventre M, Gracia Medina EA, et al. (2014) The clinical features, management and prognostic effects of pathological fractures in a multicenter series of 373 patients with diffuse large B-cell lymphoma of the bone. Ann Oncol 25: 176-181. 